\title{
Effect of municipal solid waste on bacteria population in soil
}

\author{
Simeon P. Okpoitari, Ambah Binaebi \\ Department of Agricultural Education, Jasper Adaka Boro College of Education, \\ Sagbama, Nigeria
}

\begin{abstract}
The effect of municipal solid waste on bacteria (Heterotrophic bacteria \& Nitrobacteria) population was determine by collecting $50 \mathrm{~g}$ sample's of various dumpsites, put in $2 \mathrm{~kg}$ buckets soil and kept in the green house to mimic the natural environment for six (6) weeks. Analysis of variance (ANOVA) and least significant difference (L.S.D) were effected on the data at $5 \%$ probability level. The analysis shows significant effect, this seem to suggest that municipal solid waste influences Heterotrophic bacteria and Nitrobacter population in soils.
\end{abstract}

Keywords: population; municipal; waste; dumpsite; bacteria

\section{INTRODUCTION}

Municipal Solid Waste is a common phenomenon in sub-sahavan Africa and other parts of the world. The difficulty in controlling municipal waste resulting from households, institutions and industrial activities, it has become a menance oviasogie et al (2010). Despite the fact that integrated waste management is in vogue globally Sridha 2009 and Ebekwe et al (2010), management of municipal solid waste is still a failure in this part of the world due to no proper dump sites and facilities. In municipal waste dumpsites we have mostly biodegradable and non biodegradable. The biodegradable tend to attract bacteria which cause huge activities which the non biodegradables have little or no effects on bacteria activities. Yenagoa and environs is a new state capital with huge construction activities with massive influence of human population. These have lead to large quantum of food residues ranging from plants to other biodagrables. Materials like sand, paint, sawdust, iron rods, PVC materials and other chemicals that are associated with the building industry are common sites. The Yenagoa environment being a humid area has accumulation of aerobic and anaerobic bacteria which depend on substrates that make them to survive. Municipal waste dumpsite are designated places set aside for waste disposal. Depending on the city level of waste management, such waste may be dumped in an uncontrolled manner, segregated for recycling purposes or simply burnt. Poor waste management poses a great challenge to the well being of city residents particularly those who leave close to dumpsites. This is expressed more on health situations like odour, flies and rodents (Drew et al 2007; WRAP and CIWM 2009 Lou and Naw (2009). The presence of all these nuisance have the potential of polluting water, food, land, air and vegetation Elizabeth et al (2003). If not properly handled and managed the 
resultant environmental impact these waste can be disastrous. Obire et al 2002. According to molter et al (2009) municipal waste made of mostly of food substrate and plants attract bacteria. Most purifying bacteria always attach to plants and animals and their derivatives Qautam et al (2012). A study carried out by Jilan; 2007, found out that bacteria population increase more in dumpsites than begin land with the teething problem of municipal solid waste and consequent bacteria effects the study was made to determine bacteria population on dumpsites.

\section{MATERIALS AND METHODS}

The effect of municipal solid waste on bacteria population was investigated within Yenagoa metropolis. Yenagoa lies between latitude $0415^{11}$ North, $0523^{11}$ South and longitude $0522^{11}$ West and 064511 East.

Yenagoa is an up coming city with rapid population growth which lies within heavy rainfall zone. Five sampling locations were established within Yenagoa metropolies. The locations are as follows.

$\begin{array}{ll}\text { Location } 1 \mathrm{a} & \text { Agudama-Epie } \\ \text { Location } 1 \mathrm{~b} & \text { Control. } \\ \text { Location } 2 \mathrm{a} & \text { Tombia Road } \\ \text { Location } 2 \mathrm{~b} & \text { Control. } \\ \text { Location } 3 \mathrm{a} & \text { Swali } \\ \text { Location } 3 \mathrm{~b} & \text { Control. } \\ \text { Location } 4 \mathrm{a} & \text { Igbogene } \\ \text { Location } 4 \mathrm{~b} & \text { Control. } \\ \text { Location } 5 \mathrm{a} & \text { Biogbolo } \\ \text { Location } 5 \mathrm{~b} & \text { Control. }\end{array}$

At each location municipal Solid Waste were randomly collected at a depth of $(0-30 \mathrm{~cm})$ with the aid of soil auger and were placed into a well labeled polythene bags and pulverized differently. Control samples were collected from fallow plots of each location from a distance of $100 \mathrm{~m}$ away from each dump-site. Weight of $50 \mathrm{~g}$ of municipal solid waste was weighed into $2 \mathrm{~kg}$ bucket and the control samples were also weighed into the buckets which were replicated three (3) times totaling thirty (30) plastic buckets, which were kept in the green house.

The samples were watered continuously for twenty (20) days before planting maize plant. There the buckets were allowed fallow for another ten days with constant watering before the second planting. At the end of the two cycles samples were collected, and then isolation and identification of heterotrophic and Nitrobacteria population was determine by using serial dilution procedure described by Ofunne (1999).

The study is a Randomized complete design (RCD) which was replicated three (3) times Analysis of variance (ANOVA) and Least significant difference were used to separate the means at $5 \%$ probability level Wahua (1999). 


\section{RESULT}

From the study, observations, data collection and statistical analysis were made. The bacteria population of heterotrophic and Nitrobacteria were checked within the two planting cycles and the results shown in Table 1 and Figure 1 respectively.

Table 1. Effect of municipal solid waste on bacteria population.

\begin{tabular}{|c|c|c|}
\hline DUMPSITE & $\begin{array}{c}\text { HETEROTROPHIC } \\
\left.\text { BACTERIA (CFU 10 }{ }^{3}\right)\end{array}$ & $\begin{array}{l}\text { NITROBACTER } \\
\quad\left(\text { CFU 10 }{ }^{3}\right)\end{array}$ \\
\hline $1 \mathrm{a}$ & 4.50 & 2.56 \\
\hline $1 b$ & 1.89 & 2.00 \\
\hline $2 a$ & 1.24 & 0.78 \\
\hline $2 b$ & 1.24 & 1.44 \\
\hline $3 a$ & 3.83 & 1.44 \\
\hline $3 b$ & 0.78 & 1.11 \\
\hline $4 a$ & 2.93 & 3.56 \\
\hline $4 b$ & 2.52 & 3.11 \\
\hline $5 a$ & 4.94 & 2.00 \\
\hline $5 b$ & 6.91 & 4.78 \\
\hline LSD & 0.41 & 1.09 \\
\hline
\end{tabular}

$\mathrm{P}(<0.05)$ Agudama dumpsite and control (1a \& 1b), Tombia dumpsite and control (2a \& $2 b)$, Swali dumpsite and control ( $3 a \& 3 b$ ), Igbogene dumpsite and control ( $4 a \& 4 b)$ and Biogbolo dumpsite and control (5a \& 5b). 


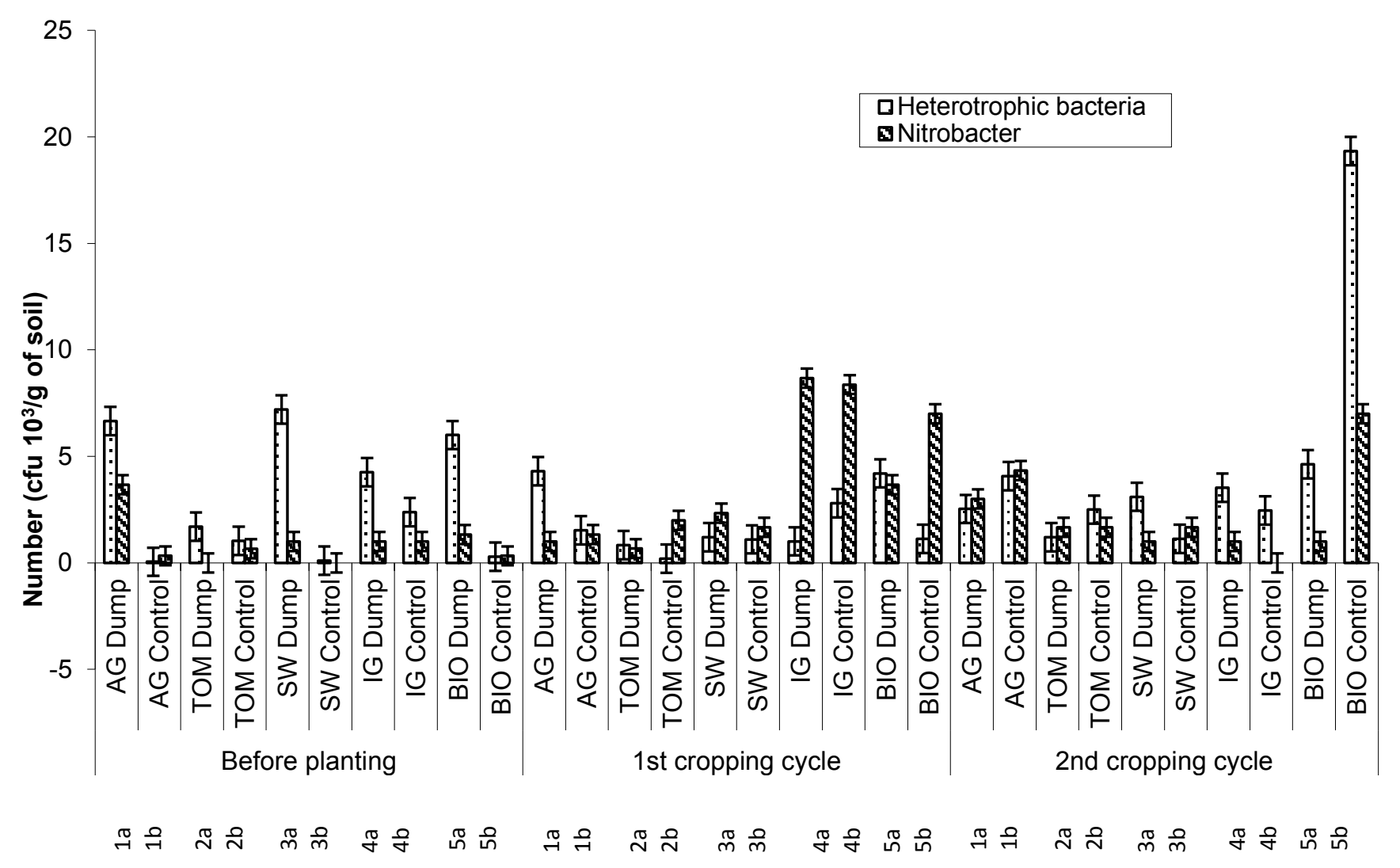

Fig. 1. Effect of cropping cycle on Nitrobacter and Heterotrophic bacterial population in soil (6WAP).

\section{DISCUSSION AND CONCLUSION}

As shown in Table 1 and Figure 1 respectively various dumpsites had significant difference in the number of heterotrophic and Nitrobacter enumerated.

Apart from $5 \mathrm{~b}$ sample that had a higher number of heterotrophic bacteria counted with a mean value of $6.91 \mathrm{cfu} 10^{3}$ that its dumpsite with a mean values of $4.95 \mathrm{cfu} 10^{3}$ heterotrophic bacteria enumerated. Dumpsites of $2 a$ and $2 b$ recorded the lowest values of $1.24 \mathrm{cfu} 10^{3}$.

Probably this could be as a result of the near abandon nature of the dumpsite which actually lack fresh waste and bacteria activities were winding up. This is in agreement with the works of Oviasogie ef al (2010) and Obire et al (2002).

The earlier low concentration of heterotrophic and Nitrobacter before a gradual rise in most dumpsites was as a result of gradual growth of bacteria population due to supply of waste and decomposition. It is in agreement with the work of Ghaly \& Alkoalk (2010). 


\section{References}

[1] Drew G., Tarmer Vestlund A., Hough R. L., Chackiath S. J., Broomfied M., Longhurst P. S. (2007). Health Impart assessment of alternate week waste collection of bio degrable waste. Presented at CIWM conference June 2007.

[2] Elizabeth A., Martin M. A ., Aggrewal R., Jobling J. C., Taylor E., Oxford Concise Medical Dictionary, $6^{\text {th }}$ Edition Oxford University Press Hong Kong, 2003, 754 pp.

[3] Gaufam, S. P., Bundela, P. S., Panadey A. K, Jamaluddin M. K., Awasthi and Sarsaiya S. (2012). Diversity of cellulitic microbes and Bio degradation of Municipal Solid Waste by a Potential Strain. International Journal of Microbiology (2012), 12 pages. doi $10.1155 / 2012 / 325907$

[4] Ghaly A. E., Alkoaik F. N., America Journal of Agricultural and Biological Science 5(3) (2010) 274-281.

[5] Ibekwe Titus S., Andrew E. Dongo, Mynepalli K. C., Sridhar, Nigeria Journal Public Health and Epidemiology 2(4) (2010) 82-86.

[6] Jilani S., Pakistani Journal of Botary 39(1) (2007) 271-277.

[7] Lou Y. F, Nair J., Bioressouce Technology 100 (2009) 3792-3798

[8] Moller J., Boldrin A., Christiansin T. H., Waste Management and Research 11(2) (2009) 91-97.

[9] Obire O., Nwallbeta O., Adue S. B. N., Journal of Applied Sciences and Environmental Management 2002 6(II) (2002) 78-83.

[10] Offune J. L. (1999). Bacteriological examination of clinical Specimens. Achugo publications, Ama J. K Recreation Park Owerri Nigeria Pp. 24-35.

[11] Oviasogie F. E., Ajuzie C. U., Igodaro U. G., Archives of Applied science Research 2(5) (2010) 161-167.

[12] Tzortzakis N. G., Boland A., Singleton I., Barnes J. (2009). Impact of atmosphere Ozore-enrichment on quality-related attributes of tomato fruit, post-harvest Biology and Technology, 45(3) (2007) 317-325.

[13] Wahua T. A. T. (1999). Applied Statistics for Scientific Studies. Afrika-Link Books University of Ibadan, Pp. 124-141.

[14] WRAP and CIWM (2009). Scoping study of potential Health effects of fortnightly residual waste collections and related changes to domestic waste systems. 